Buddayah: Jurnal Pendidikan Antropologi, Volume 1, Nomor 1, 2017, 14-18

\title{
KEPERCAYAAN MASYARAKAT BATAK TOBA TERHADAP ADANYA SIGUMOANG (ROH JAHAT) DI DESA SIMANAMPANG KECAMATAN SIATAS BARITA KABUPATEN TAPANULI UTARA
}

\author{
Devi Rianti Sinaga \\ Alumni Prodi. Pendidikan Antropologi Fakultas Ilmu Sosial Unimed \\ Puspitawati \\ Staf Pengajar di Prodi. Pendidikan Antropologi Fakultas Ilmu Sosial Universitas Negeri Medan \\ puspita.ratmono@yahoo.co.id
}

\begin{abstract}
Abstrak
Penelitian ini bertujuan mengetahui bagaimana kepercayaan masyarakat Desa Simanampang terhadap adanya sigumoang (roh jahat) dan bagaimana kepercayaan ini dapat bertahan sampai sekarang di Desa Simanampang. Penelitian ini merupakan penelitian kualitatif dengan pendekatan deskriftif yang bertujuan agar data yang diharapkan sesuai dengan data yang diperoleh. Penelitian ini dilakukan melalui observasi dan wawancara kepada informan. Yang menjadi informan dalam penelitian ini adalah masyarakat Desa Simanampang dengan informan kunci adalah orangorang yang mengetahui permasalahan dalam penelitian ini. Penelitian ini menemukan bahwa masyarakat percaya terhadap adanya sigumoang (roh jahat) yang pelihara oleh seseorang untuk kepentingan tertentu tetapi merugikan orang lain kemudian untuk menghindari ulah sigumoang tersebut masyarakat mempercayai bahwa darah babi dapat mengusir sigumoang dan mereka dapat terlindung dari ulah jahatnya. Faktor-faktor yang mempengaruhi kepercayaan ini dapat bertahan sampai sekarang ialah kebiasaan lama, mitos, adanya oknum yang telah mengaku memelihara sigumoang, dan kondisi masyarakat yang belum keseluruhan tersentuh budaya modern sehingga masyarakat sulit menerima perubahan.
\end{abstract}

Kata Kunci: Roh Jahat, Mitos, Kepercayaan, Kebiasaan lama

\section{PENDAHULUAN}

Bangsa Indonesia adalah bangsa yang majemuk, yang memiliki keberagaman budaya, suku, ras, agama dan lain-lain. Keberagaman yang dimiliki suatu bangsa dapat dijadikan sebagai kekayaan dan keindahan bangsa itu sendiri.

Di Sumatera Utara terdapat banyak suku bangsa, diantaranya adalah suku Batak. Suku Batak mempunyai sub-sub suku bangsa yaitu Karo, Simalungun, Pakpak, Toba, Angkola dan Mandailing (Koentjaraningrat, 2007). Batak toba merupakan sub suku Batak yang menyebar kesegala penjuru daerah Tapanuli, Simalungun, Dairi dan daerah lainnya, dalam perantauan tersebut kebiasaan dan kepercayaan yang mereka yakini turut dibawa. Sebagian besar suku bangsa Batak Toba kini telah memeluk agama yakni Kristen protestan (sebagian besar) ada juga Kristen, Katolik, Islam dan sebagainya, tetapi pada masa lalu mereka mempercayai Mula Jadi Nabolon.

Mula jadi Na Bolonlah yang maha kuasa tetapi masih ada lagi yang berkuasa yang lain, yaitu yang dirasakan memiliki kekuatan, seperti pohon beringin, mata air, batu besar, gunung dan sebagainya. Demikianlah pengetahuan mereka pada waktu itu.

Selain dari Mula Jadi Nabolon dan mempercayai kekuatan alam seperti pohon besar, mata air, batu besar dan sebagainya ada lagi kepercayaan lain yaitu sahala dan simangot yang mempunyai kepercayaan yang membuat susah dan berbagai kesulitan. Adat dan budaya saling mempengaruhi dengan kepercayaan itu, memang sebelum agama datang banyak manusia didunia ini animisme dan dinamisme yang menyembah berhala sedangkan yang memegang peranan dalam setiap persembahan, kejadian atau acara adalah dukun seperti jika ada yang sakit, susah, berpesta atau mendirikan rumah harus menurut petunjuk dukun.

Tentang kedukunan, pengobatan ada ditulis dalam tulisan batak yang tertulis pada buku lak-lak. Ada kalanya mereka pukul gendang untuk menyembah Mula Jadi dan memohon restu dari kekuatan yang lain.

Semua manusia sadar akan adanya suatu alam dunia yang tak tampak, yang ada diluar batas inderanya dan diluar batas akalnya. Dunia adalah dunia gaib atau supranatural. Menurut kepercayaan manusia dalam banyak kebudayaan di dunia, dunia gaib didiami oleh berbagai makhluk dan kekuatan yang tak dapat dikuasai manusia dengan cara-cara biasa, dan oleh karena itu pada dasarnya ditakuti oleh manusia (Koentjaraningrat, 1981). Ruh-ruh leluhur, ruh-ruh lainnya, hantu dan sebagainya dianggap juga oleh suku bangsa di dunia sebagai penduduk dunia gaib.

Tetapi setelah agama datang secara perlahan adaptasi adat atau budaya dengan animisme berubah menjadi adaptasi adat dengan agama. Mereka semakin yakin bahwa yang patut disembah ialah Tuhan yang disebut Mula Jadi Nabolon adalah Tuhan Yang Maha 
Esa, fungsi dukun tidak ada lagi tetapi adat dan budaya tetap berjalan terus. Sekarang yang membawa peranan dalam acara ialah Raja Adat, Pemuka Agama dan tokoh masyarakat. Sekarang sebaiknya adat atau budaya dan agama diadaptasi untuk menjadi suatu alat untuk memuliakan Tuhan (Situmorang, 1995)

Kini manusia menikmati jaman keterbukaan yang dapat memantau segala perkembangan termasuk budaya asing melalui informasi canggih. Anggapannya budaya sendiri kurang menarik/kolot, sehingga semakin tergeser oleh aneka ragam budaya asing yang menarik perhatian mereka. Yang paling mengherankan dijaman iptek ini ialah: kepercayaan orang terhadap kekuatan gaib. Masih banyak masyarakat, pakar ilmu, orang berpangkat bahkan orang yang beragama dipengaruhi oleh dukun. Hal ini ialah peninggalan kepercayaaan lama (Situmorang, 1995)

Salah satu suku yang mempercayai adanya dunia gaib ialah suku Batak Toba. Batak toba tinggal dan menetap di berbagai daerah salah satu nya adalah kabupaten Tapanuli Utara yang terdiri dari beberapa kecamatan diantara nya adalah Kecamatan Siatas Barita yang terdiri dari beberapa Desa dan mayoritas penduduknya adalah masyarakat Batak Toba.

Di setiap Desa banyak mitos yang masih melekat khususnya pada masyarakat Batak Toba bahkan sampai sekarang masih dipercayai, salah satu nya ialah masyarakat Desa Simanampang kecamatan Siatas Barita Kabupaten Tapanuli Utara yang percaya adanya sigumoang (roh jahat). Sigumoang dipercaya masyarakat tersebut adalah makhluk halus yang jahat yang dapat mendatangkan bencana dan biasanya di pelihara oleh seseorang yang bermaksud tidak baik pada orang lain atau bermaksud tertentu dengan kepentingan tertentu.

Sigumoang adalah begu atau hantu yang dipercaya ada sampai sekarang bahkan mayarakat yang sudah memiliki Agama pun tetap mempercayainya,. Masyarakat tersebut percaya adanya sigumoang dan dipelihara oleh seseorang untuk hal-hal tertentu yang menguntungkan dirinya seperti memberi penyakit aneh pada orang lain dan yang mendapat penyakit tersebut diusulkan supaya berobat kepadanya, hal ini akan menguntungkan ekonomi sipemelihara sigumoang tersebut selain untuk kepentingan ekonomi sipemelihara sigumoang juga mempergunakan sigumoang untuk kepentingan lain. Masayarakat Desa tersebut pada umumnya sulit menemmukan bukti konkrit pada seseorang yang diduga memelihara sigumoang namun Jika ada seseorang yang terbukti memelihara sigumoang maka dia akan dijauhi masyarakat tidak hanya sipemelihara bahkan keluarga nya pun akan ikut-ikutan dijauhi karena dianggap keluarga pembawa bencana.

Agar masyarakat terhindar dari ulah sigumoang yang ditakuti masyarakat maka masyarakat didaerah tersebut menggunakan darah babi sebagai simbol untuk mengusir sigumoang dan anti sigumoang dengan cara menggoreskan darah babi di pintu rumah mereka dengan kepercayaan sigumoang tidak akan masuk kedalam rumah mereka..

Mengapa kepercayaan ini masih bertahan sedangkan masyarakat sudah memeluk Agama dan bagaimana konflik yang terjadi pada masyarakat akibat dari kepercayaan adanya sigumoang? dan darah babi yang dipercaya masyarakat sebagai penangkal sigumoang merupakan hal yang unik dari kepercayaan ini yang menjadi latar belakang penulis dan tertarik untuk meneliti mengenai kepercayaan masyarakat Batak Toba terhadap adanya sigumoang (Roh Jahat).

\section{METODE PENELITIAN}

Pada penelitian ini, peneliti menggunakan metode kualitatif yang dilaksanakan dengan pendekatan deskriptif. Pendekatan kualitatif adalah salah satu jenis metode penelitian yang berusaha menggambarkan dan menginterpretasi objek sesuai dengan apa adanya. Penelitian Deskriptif ini juga sering disebut noneksperimen, karena pada penelitian ini peneliti tidak melakukan kontrol dan manipulasi variabel penelitian.

Dengan penelitian metode deskriptif, memungkinkan peneliti untuk melakukan hubungan antar variabel, menguji hipotesis, mengembangkan generalisasi, dan mengembangkan teori yang memiliki validitas universal. Hal ini artinya penelitian akan menggambarkan data tentang kepercayaan masyarakat Batak Toba yang telah memiliki Agama terhadap adanya Sigumoang.

\section{HASIL DAN PEMBAHASAN}

\section{Kepercayaan Masyarakat Terhadap Adanya Sigumoang (Roh Jahat)}

Teori yang disampaikan oleh E.B Tylor (Baal, 1987: 85) kepercayaan terhadap adanya dunia gaib merupakan primitive culture. Mempercayai adanya dunia gaib menurut masyarakat simanampang adalah budaya primitif sebelum budaya modern masuk ke Desa ini namun karena kondisi masyarakat yang belum keseluruhan disentuh oleh budaya modern maka kepercayaan ini masih ada sampai sekarang seperti mempercayai adanya makhluk gaib yakni sigumoang.

Dari hasil penelitian menemukan bahwa kepercayaan terhadap adanya sigumoang sudah ada sejak lama di Desa tersebut tetapi mereka masih mempercayainya hingga sekarang dikarenakan masyarakat yang masih mempercayainya adalah penduduk yang sudah menetap di Desa tersebut sejak lama. Tetapi walaupun mereka mempercayai hal tersebut kepercayaan mereka yang terutama adalah Tuhan Yang Maha Esa setelah datang nya agama, kepercayan masyarakat Desa Simanampang yang terutama adalah kepada Tuhan Yang Maha Esa meskipun mereka percaya 
adanya sigumoang yang dapat mengganggu mereka dan mempercayai darah babi dapat mengusir sigumoang agar mereka terlindungi dari ulah sigumoang tetapi yang terutama mereka mempercayai Tuhan yang dapat melindungi mereka dari hal-hal jahat, selain itu masyarakat Desa simanampang ternyata ada beberapa yang tidak mempercayai adanya sigumoang yang bertolak belakang dengan mayoritas penduduk Desa tersebut yang mempercayai adanya sigumoang, masyarakat yang tidak mempercayainya merupakan penduduk pendatang di Desa tersebut dan sudah memiliki pengalaman merantau ke daerah lain sehingga pemikiran mereka lebih mudah menerima perubahan sehinggan kepercayaan lama tersebut mulai memudar dari pemikiran mereka.

\section{Faktor Yang Mempengaruhi Kepercayaan Terhadap Adanya Sigumoang Bertahan Sampai Sekarang}

Kepercayaan terhadap adanya sigumoang yang sudah ada sejak dulu bertahan hingga sekarang tentu ada faktor yang menyebabkannya. Penelitian menemukan bahwa kepercayaan terhadap adanya sigumoang dapat bertahan hingga saat ini dilatar belakangi oleh faktor kebiasaan dahulu yang berkembang di masyarakat ini dan juga sikap masyarakat yang tradisional dan. Kebiasaan berpengaruh besar terhadap pembentukan prilaku masyarakat itu sendiri. Disaat zaman sudah maju, pola pikir seorang atau kelompok bisa berubah seperti rasionalitas berpikir. Namun pola pikir pada masyarakat ini sulit berubah. Selain itu faktor yang melatar belakangi kepercayaan ini adalah mitos yang berkembang.

Mitos yang berkembang di masyarakat dapat memiliki kekuatan untuk mempengaruhi pola pikir masyarakat, hingga masyarakat memiliki kekhawatiran dalam hidup masing-masing dan bahwa dunia penuh dengan kekuatan-kekuatan gaib dan adanya makhluk gaib. Hal ini berlawanan dengan rasionalis (yang mendewakan rasio atau akal budi serta kemampuan berpikir ilmiah) yang memandang rendah terhadap mistis yang ada

Penelitian menemukan bahwa mempercayai adanya sigumoang yang sudah ada sejak dahulu dan bertahan sampai sekarang dikarenakan sikap tradisional masyarakat Desa yang belum tersentuh budaya modern dan pola pikir yang modern.

Hasil wawancara menenukan bahwa walaupun masyarakat Desa mempercayai adanya sigumoang dan darah babi untuk mengusir sigumoang agar terlindung dari ulah jahat sigumoang tetapi yang terutama masyarakat percaya terhadap Tuhan sang pencipta yang menguasai langit dan Bumi. Faktor-faktor yang menyebabkan masyarakat percaya adanya sigumoang adalah

1. Kepercayaan lama, kebiasaan dahulu yang berkembang di masyarakat ini dan juga sikap masyarakat yang tradisional dan belum keseluruhan tersentuh budaya modern

2. Setelah adanya oknum yang mengakui telah memelihara sigumoang, hal ini membuat masyarakat percaya akan adanya sigumoang.
3. Adanya kejadian-kejadian aneh yang terjadi di Desa tersebut seperti masyarakat yang meninggal tidak wajar, penyakit yang aneh dan lainnya.

4. Mitos yang berkembang di masyarakat dapat memiliki kekuatan untuk mempengaruhi pola pikir masyarakat, hingga masyarakat memiliki kekhawatiran dalam hidup masing-masing dan bahwa dunia penuh dengan kekuatan-kekuatan gaib dan adanya makhluk gaib.

\section{Penggunaan Darah Babi untuk Mengusir Sigumoang}

\subsection{Awal Mula Darah Babi di Percaya Mengusir Sigumoang}

Menurut A.B Sinaga suku Batak Toba mengenal Jimat parsimboraan yakni penangkal untuk melawan kekuatan-kekuatan hantu atau roh jahat (Simanjuntak, 2009). Pendapat beliau sejalan dengan kepercayaan masyarakat Desa Simanampang terhadap darah babi sebagai penangkal ulah jahat sigumoang. Masyarakat Desa Simanampang menggunakan darah babi untuk mengusir sigumoang dan anti sigumoang dengan cara menempelkan darah babi yang berbentuk telapak tangan manusia ke pintu masuk rumah dan jendela bahkan ada juga yang membuat nya ke gubuk di perladangan mereka dengan kepercayaan bahwa sigumoang tidak akan masuk ke dalam rumah mereka dan tidak akan mengganggu mereka.

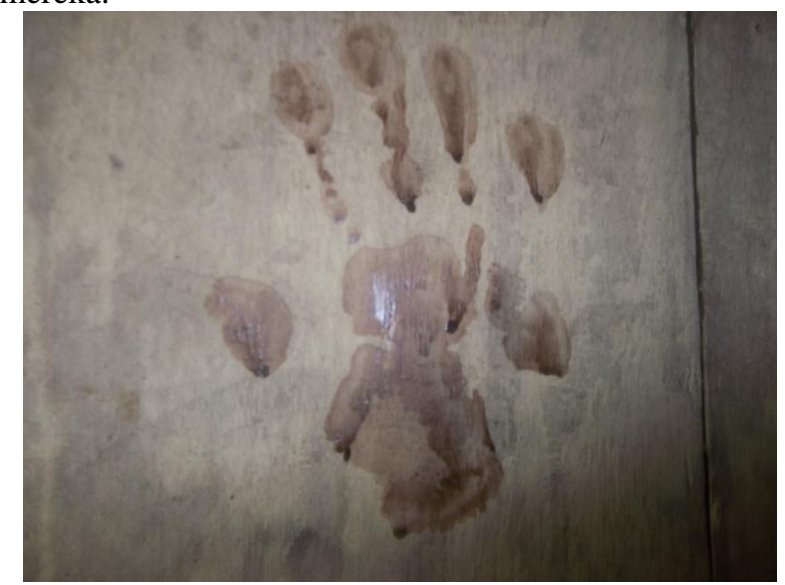

Gambar 1: Cap darah babi yang berbentuk tangan manusia

Menurut Bapak S. Tampubolon selaku salah seorang tokoh masyarakat yang sudah lama bertempat tinggal di Desa tersebut ialah awal mula nya digunakan darah babi untuk mengusir sigumoang adalah ketika waktu beberapa tahun lalu syakni sekitar tahun 1998 ada isu-isu seseorang memelihara sigumoang. Isu sigumoang ini merebak dimasyarakat disebabkan adanya kematian yang tidak wajar dimasyarakat. Kematian tersebut diduga ulah dari sigumoang. maka isu sigumoang di Desa ini dengan cepat menyebar keseluruh Desa dan juga ke Desa tetangga. Hal ini tentu saja sangat meresahkan masyarakat, membuat masyarakat takut keluar rumah. Masyarakat juga takut melaksanakan aktifitas diperladangan, dan anak-anak takut untuk sekedar bermain diluar rumah. 
Tidak ingin isu sigumoang terus menghantui msayarakat maka para penatua, tokoh adat, tokoh agama berkumpul untuk mengadakan musyawarah penyelesaian masalah tersebut tanpa melibatkan pihak aparat hukum. Tokoh adat pun mengusulkan untuk membuat suatu upacara yaitu sumpah. Bagi siapa yang memelihara sigumoang dikemudian hari akan mendapat bala misalnya penyakit atau bahkan kematian. Maka pada hari itu juga seluruh masyarakat dikumpulkan ditengahtengah Desa, lalu para tokoh masyarakat mempersiapkan kebutuhan dalam pelaksanaan acara tersebut yakni memotong seekor babi dan mengambil jantung nya, kemudian diikat dan digantung di tengah halaman tempat acara tersebut, dan paku besar.

Setelah semua lengkap maka acara dimulai dengan penyampaian maksud dan tujuan masyarakat dikumpulkan oleh salah seorang tokoh masyarakat. Pelaksanaan sumpah ini hanya diberlakukan kepada orang dewasa saja, karna anak-anak dianggap tidak mungkin memelihara sigumoang. Kemudian tokoh masyarakat memerintahkan untuk menusuk jantung babi tersebut dengan paku yang besar secara bergantian dengan kepercayaan jika ada diantara masyarakat yang disumpah tersebut memelihara sigumoang maka dia akan mendapatkan bala seperti penyakit bahkan kematian.

Setelah seluruh masyarakat selesai menusuk jantung babi tersebut darah babi yang dipotong dibagikan kepada seluruh masyarakat dengan tujuan agar masyarakat menempelkannya disetiap dipintu rumah dengan menggunakan telapak tangan. Darah babi berbentuk telapak tangan manusia tersebut harus disertai dengan penulisan kata "muttul sigumoang dihuta nang dibalian".

Dari hasil penelitian menemukan bahwa awal mula masyarakat percaya darah babi dapat mengusir sigumoang adalah ketika beberapa tahun lalu terjadi isu sigumoang yang sangat meresahkan masyarakat dengan kejadian-kejadian aneh di Desa tersebut kemudian tokohtokoh masyarakat bermusyawarah untuk membuat upacara sumpah di Desa tersebut dengan dipotong nya seekor babi lalu jantungnya ditusuk secara bergilir dan darahnya dibagi kepada seluruh penduduk untuk ditempelkan kepintu rumah mereka agar dapat melindungi rumah mereka dari ulah sigumoang lalu masyarakat mengikuti perintah tokoh-tokoh masyarakat tersebut lalu melakukannya hingga mempercayainya hingga sekarang dan penggunaan darah babi tersebut mempunyai arti khusus yang sudah turun temurun bagi masyarakat Desa Simanampang. Karena menurut mereka kotoran babi saja bisa menyadarkan orang yang kesurupan.

\subsection{Makna simbol Telapak Tangan dan Darah Babi} Bagi Masyarakat Untuk Mengusir Sigumoang

Darah Babi yang di tempelkan berbentuk tangan manusia pada pintu dan jendela rumah masyarakat memiliki arti dan maksud tertentu bagi masyarakat Desa simanampang yang mempercayai. Hasil penelitian menemukan bahwa darah babi dan bentuk telapak tangan memiliki arti dan masuk. Darah babi yang mereka percaya adalah benda yang di takuti sigumoang sedangkan simbol telapak tangan artinya adalah menolak atau mengusir.

\section{Konflik Sosial dan Tindakan Sosial dalam Masyarakat}

Menurut Dahrendorf, isu yang tidak jelas asalusulnya memiliki dampak terhadap masyarakat seperti konflik sosial. Masyarakat tak akan ada tanpa konsensus dan konflik yang menjadi persyaratan satu sama lain. Jadi kita tak akan punya konflik kecuali ada konsensus sebelumnya (Ritzer dan Godman, 2003). Dalam masyarakat Desa Simanampang terjadi konflik yang bermula dari kepercayaan terhadap adanya sigumoang yaitu isu adanya pemelihara sigumoang, ciri-ciri yang dianggap masyarakat memelihara sigumoang seperti bertingkah laku aneh, tidak memakai alas kaki, jarang keluar rumah, tidak mau bergabung dalam masyarakat lainnya terutama dalam acara-acara Desa.

Penelitian menemukan bahwa potensi konflik yang terjadi sebagai akibat dari kepercayaan ini, yaitu:

1. Karna tiadanya bukti mengakibatkan yang tertuduh pemelihara sigumoang tidak dapat dijerat hukum. Karna kasus ini berbau magis alias metafisika tidak ada pasal yang menyangkut ini. Sehingga tidak ada hukuman pidana bagi yang tertuduh. Jika sampai terjadi penganiayaan terhadap tertuduh maka palaku penganiayaan inilah yang bisa terjerat hukum.

2. Terjadi nya Pro dan Kontra yakni percekcokan antara masyarakat yang mempercayai dengan yang yang tidak mempercayai

3. Terjadinya rasa saling mencurigai antara masyarakat

4. Terjadinya kekerasan jika ada yang terbukti memelihara sigumoang seperti di pukul masa bahkan sampai di usir dari Desa tersebut

Tindakan masyarakat dalam mengusir oknum yang telah mengaku sebagai pemelihara sigumoang merupakan tindakan rasional instrumental yang dikemukakan oleh Weber dalam Sunarto (2000) bahwa tindakan ini memiliki tujuan agar oknum pemelihara sigumoang jauh dari Desa mereka dan tidak akan dapat mengganggu mereka lagi, sedangkan tindakan masyarakat yang memukuli oknum pemelihara sigumoang saat menakui perbuatannya merupakan tindakan afektif yang juga dikemukakan oleh Weber dalam Sunarto (2000) yakni tindakan ini merupakan hasil luapan emosi masyarakat setelah mendengar pengakuannya kemudian tindakan masyarakat yang menggunakan darah babi untuk mengusir sigumoang merupakan tindakan Tradisional yang juga dikemukakan oleh Weber dalam Sunarto (2000) yakni tindakan ini dilakukan dikarenakan kebiasaan masyarakat dari dahulu tanpa mengetahui alasan menggunakannya dan hanya berlandaskan kepercayan itu saja.

\section{PENUTUP}

Berdasarkan hasil penelitian maka dapat diambil beberapa kesimpulan, yaitu sebagai berikut:

1. Menurut masyarakat Desa Simanampang sigumoang merupakan begu atau hantu yang jahat yang ulah nya hanya membuat susah manusia dan 
sigumoang dipercaya dipelihara oleh seseorang dengan kepentingan tertentu.

2. Kepercayaan terhadap adanya sigumoang dapat bertahan hingga saat ini dilatar belakangi oleh faktor kebiasaan dahulu atau primitive cultural yang berkembang di masyarakat ini. Kebiasaan berpengaruh besar terhadap pembentukan prilaku masyarakat itu sendiri. Disaat zaman sudah maju, pola pikir seorang atau kelompok bisa berubah seperti rasionalitas berpikir. Namun pola pikir pada masyarakat ini sulit berubah. Selain itu factor yang melatar belakangi kepercayaan ini adalah mitos yang berkembang.

3. Mitos yang berkembang di masyarakat dapat memiliki kekuatan untuk mempengaruhi pola pikir masyarakat, hingga masyarakat memiliki kekhawatiran dalam hidup masing-masing dan bahwa dunia penuh dengan kekuatan-kekuatan gaib dan adanya makhluk gaib. Hal ini berlawanan dengan rasionalis (yang mendewakan rasio atau akal budi serta kemampuan berpikir ilmiah) yang memandang rendah terhadap mistis yang ada.

4. Masyarakat Desa Simanampang menggunakan darah babi untuk mengusir sigumoang dan anti sigumoang dengan cara menempelkan darah babi yang berbentuk telapak tangan manusia ke pintu masuk rumah dan jendela bahkan ada juga yang membuat nya ke gubuk di perladangan mereka dengan kepercayaan bahwa sigumoang tidak akan masuk ke dalam rumah mereka dan tidak akan mengganggu mereka.

5. Darah babi dan bentuk telapak tangan memiliki arti dan maksud. Darah babi yang mereka percaya adalah benda yang di takuti sigumoang sedangkan simbol telapak tangan artinya adalah menolak atau mengusir.

6. Masyarakat Desa tersebut mempercayai sigumoang digunakan untuk kepentingan ekonomi dengan cara memberi penyakit kepada masyarakat dan menawarkan diri untuk mengobati penyakit tersebut.

7. Karna tiadanya bukti mengakibatkan yang tertuduh pemelihara sigumoang tidak dapat dijerat hokum. Karna kasus ini berbau magis alias metafisika tidak ada pasal yang menyangkut ini. Sehingga tidak ada hukuman pidana bagi yang tertuduh. Jika sampai terjadi penganiayaan terhadap tertuduh maka palaku penganiayaan inilah yang bisa terjerat hukum.

\section{DAFTAR PUSTAKA}

Abduh, Muhammad, dkk. 1987. Pengantar Sosiologi. Medan: Fakultas Hukum USU Medan
Anwar, Dessy. 2003. Kamus lengkap bahasa Indonesia terbaru. Surabaya. Amelia surabaya

Baal. J Van. 1957. Sejarah dan pertumbuhan teori antropologi budaya. Jakarta. PT Gramedia

Coser, Lewis. 1967. Continuities in the study of sosial conflict. New York. Free press

Durkheim,Emile. 2001. The Elementary Forms of The Religious Life/sejarah bentuk-bentuk agama yang paling dasar. IRCiSoD. Yogyakarta

Hadi, Y Sumandiyo. 2006. Seni dalam ritual Agama. Yogyakarta: Pustaka

Hanti, Hotsri. 2014. Kepercayaan terhadap tempat keramat. Medan. USU

Idianto. 2000. Sosiologi. Jakarta. Erlangga

Koentjaraningrat. 1980. Beberapa Pokok Antropologi sosial. Jakarta: Dian Rakyat

Jakarta: Rineka Cipta

Maran, Rafael Raga. 2007. Manusia dan Kebudayaan dalam Perspektif Ilmu Budaya Dasar. Jakarta: Rineka Cipta

Nainggolan, Enny. 2011. Prilaku Mamele untuk mendapatkan Status. 2011. Medan. USU

Tambunan, E,H. 1982. Sekelumit mengenai Masyarakat Batak Toba dan Kebudayaannya. Bandung: TARSITO

Paul B. Horton dan Chester L. Hunt. 1999. Sosiologi. Jakarta: Erlangga

Ritzer, George dan GoodMan, Douglas. 2003. Teori Sosiologi Modern. Jakarta. Prenada Media

Simanjuntak,B.A. 2009. Konflik Status dan Kekuasaan Orang Batak Toba. Jakarta. Yayasan Obor Indonesia

Sugiyono. 2008. Metode Penelitian Pendidikan. Bandung: Alfabeta

Sunarto, Kamanto. 2000. Pengantar sosiologi. Jakarta. Fakultas Ekonmi Universitas Indonesia

Sudrajat, Ajat. 1954. Sosiologi Agama "Agama dan tipe masyarakat”. Yoyakarta: Gunadarma

Spradley, James P. 2007. Metode Etnografi. Yogyakarta: Tiara Wacana

Sarumpaet,J.P. 1994. Kamus Batak Indonesia. Jakarta. Erlangga 